\title{
Evaluation of Performance of Photovoltaic Thermal Hybrid System
}

\author{
Amandeep Singh \\ Department of Electrical Engineering \\ Baba Banda Singh Bahadur Engineering College \\ Fatehgarh Sahib, India
}

\begin{abstract}
Renewable Energy including solar energy opportunities are endless, with the increase in the rate of depletion of fossil fuels. It is well known Photovoltaic cells convert solar energy into electricity but it is also true that the efficiency of conversion decreases with rising temperature due to increased resistance after certain centigrade of temperature. Thus for improving the efficiency beyond that limits by lowering the thermal resistance and allowing the use of any cooling fluid (air/water) seems an attractive option. This cannot be generalized as a performance of the PVT system based upon climate conditions varies location wise. In this paper, the study is focused on small size PVT/WATER system that is set up for one family house. Results depict that the use of the cooling technique to cool the (PV/T) system contributes to strengthen the solar cell operation to a large extent and an increase in efficiency of System is observed with a decrease in thermal resistance.
\end{abstract}

Keywords-PV/T Collector, Thermal efficiency, Electrical efficiency, Solar Energy

\section{INTRODUCTION}

In Today`s world, every sector like industrial, agricultural, medical, transportation, household, etc needs the energy to fulfill the daily needs. For decades, one of the major/primary sources of energy generation is fossil fuels. Now with the time being, a rapid growth rate of population allied with modernization and urbanization lay to the increasing demand of energy leading to the aggressive consumption of fossil fuels. With all these increments in usages, the rate of rising pollution goes upward to a dangerous/alarming level, In such a scenario, Researchers are paying a lot of attention to integrated and clean use of all types of energy that includes both renewable to non-renewable sources. Renewable energy sources are taken as environment-friendly sources compared to its other counterparts as it helps to maintain the balance with the ecosystem by contributing negligible pollution to the environment.[1] Renewable energy technology provides an opportunity for developing countries like india to ease the burden of imports of highly depleting fossil fuels.

Solar energy is abundant in nature and in the last few decades the applications of the solar technology is rapidly increasing. The most widely and significantly adopted technology is extraction of electricity from solar energy through photovoltaic cell (PV cell) and use of solar thermal collectors for direct and indirect heating processes. It is very well defined that Solar energy conversion efficiency of PV cells is relatively low and with increase in temperature beyond certain limits the efficiency tends to reduce further as increase in temperature increase the thermal resistance in PV cell.[2] However, with the fusion of Solar Collector (Air/Water) with
PV cell, useful energy can be obtained by increasing the electrical efficiency by lowering the temperature of the PV Panel's back surface. This technology is referred as Photovoltaic Thermal Technology (PVT Technology).

The combined or Hybrid Photovoltaic Thermal system are solar devices, which can simultaneously provide the heat and electricity achieving higher energy conversion rate of the absorbed solar radiation. The Concept of hybrid PV/T systems have been presented in 1978 for the first time. Lambert et al. describes that oscillating flow can significantly improve the heat transfer by increasing thermal diffusivities of the working fluids in solar collectors [3].

Several studies have been done about the use of fluids in PV/T systems considering Water or Air PV/T systems. Some of the researchers found that use of water systems seem more desirable as it allows better recovery of the heat.[4]while others suggests that the results from an applied air type PV/T system gives a variety of results regarding the effect of design module and operational parameters on the performance of air type PV/T systems [5,6]. To ensure the solar cells operates at low temperature and keep the PV module efficiency at a higher side, use of natural or forced (air or water) circulation seems to be the simple method to remove heat from the PV modules. Numerous researches are done on the analytical and experimental studies of PVT system in different places and conditions intended to find out the best results that contribute to increase the efficiency of these systems [7].

In this paper, we present the evaluation of PV/T system that uses water as heat extraction fluid (PVT/WATER), providing electricity and hot water. The suggested system is analyzed for electrical and thermal efficiencies, variations in temperature with respect to time and effect of cooling the system with water on electricity generation, i.e., difference between electricity generation with water circulation and without water circulation.

\section{PVT WATER SYSTEM CONCEPT}

The PVT water system is costlier than air type PVT systems and can be effectively used all seasons but that varies according to temperature as along with efficiency economic aspect also matters. Mainly for low latitude applications, the PVT water system is appropriate as water from the main supply is nearly $20^{\circ} \mathrm{C}$ only whereas ambient or say the atmospheric temperature is above $20^{\circ} \mathrm{C}$ almost half of the year which cut short the applications of air type PVT systems in terms of the effective electricity production.[8]

Most of the PVT models investigated to date consist of silicon PV modules and the heat extraction unit which consists of a metallic sheet with pipes for the water circulation, to avoid the 
direct contact of water with the PV system rear surface. The heat exchanger module is in thermal contact with the PV rear side that keeps the PV module cools down or thermally insulated to the ambient from the heat exchanger element rear and the panel edges.

In PVT system applications the main focused is the production of electricity So, it is necessary to keep the PV modules at low temperature to maintain or increase the cell efficiency, i.e., electrical efficiency should be at sufficient level [9]. This requirements limits the effective operation range of the PVT thermal unit in the low temperature. Thus the extracting heat can be used for the water preheating purposes. There is one thing to noticed that using PV modules without additional glazing, provides satisfactory electrical output depending on the operating conditions, but the thermal efficiency is reduced for higher operating temperatures due to the increased thermal losses from the PV module front surface[10].

It has been observed that addition of glazing surface significantly increases the thermal efficiency for a wider range of operating temperature but on the other hand reduction in electrical output of $\mathrm{PV} / \mathrm{T}$ system has been observed due to additional optical losses [11]. As PV system are taken into consideration and the cost of PV modules is on the higher sides, the main priority is for sure electrical output, but the different performance of the two subsystems regarding effect of temperature from the past observations affects the cost and optimizes modifications for both electrical and thermal efficient operation must be considered which at the end results in improved efficiency of module [12].

\section{OBJECTIVES OF THE WORKING MODEL}

The major observations to be calculated and presented in the paper are:

- Evaluating the efficiency of PVT models without the water i.e., PV system alone

- The other major objective is to determine the efficiency of PVT system with the Water and

- Evaluating the variations in the results, i.e., Variation in Open Circuit Voltage, Short Circuit Current and most important variation in electrical efficiency (which is the primary priority).

IV. EXPERIMENTAL SET-UP AND SPECIFICATIONS The systematic diagram of PVT system involved is as presented in Fig.1, The Electrical and Mechanical Characteristics of the modules used are explained in the Table- 1 and Table- 2 respectively.

\section{A. Solar Hot water Tube System}

The selective Coating on the inner cover of the evacuated tubes absorbs heats. When temperature rises, the density of water drops and weight goes down, hot water will go up to exchange with cold water in the tank which eventually lower down the temperature of solar panels and temperature of the water in the tank goes up.[13]

\section{Benefits of Solar Tube System:}

- Most efficient if installed correctly

- Can increase the efficiency according to the will of the user (in some models)

- Affordable and can be installed anywhere

Various particular specifications of the tube system taken into experimentation are elaborated in the Table-3.

Table-1: Electrical Characteristics of Module used

\begin{tabular}{|c|c|c|}
\hline S. No & Particulars & Specifications \\
\hline 1 & Model & IS-160/12 \\
\hline 2 & Maximum Power(Pmax) & 160 \\
\hline 3 & Operating Voltage (V) & 12 \\
\hline 4 & Open Circuit Voltage (Voc) & 22.32 \\
\hline 5 & Short Circuit Current (Isc) & 8.9 \\
\hline 6 & Voltage at Maximum Power Point (Vpm) & 18.6 \\
\hline 7 & Current at Maximum Power Point (Ipm) & 8.62 \\
\hline 8 & Module Efficiency & 16.24 \\
\hline 9 & Electrical Tolerance $\%$ & +5 \\
\hline 10 & Temperature & $45 \pm 2{ }^{\circ} \mathrm{C}$ \\
\hline 11 & Maximum System Voltage & $1000 \mathrm{~V}$ \\
\hline
\end{tabular}

Table-2: Electrical Characteristics of Module used

\begin{tabular}{|c|c|c|}
\hline S. No. & Particulars & Specifications \\
\hline 1 & Model & IS-160/12 \\
\hline 2 & Type of Cell & Poly-Crystalline \\
\hline 3 & Module Matrix & $9 \times 4(36$ Pcs $)$ \\
\hline 4 & Dimensions & $1481 \times 661 \times 35$ \\
\hline 5 & Weight & $11.25 \mathrm{Kg}$ \\
\hline 6 & Back sheet & Composite Film \\
\hline 7 & Front Glass & $3.2 \mathrm{~mm}$ Tempered Glass \\
\hline
\end{tabular}

Table-3: The Specification Table of Tube System (Tank)

\begin{tabular}{|c|c|c|}
\hline S.No. & Particular & Specification \\
\hline 1 & Capacity & 150 ltr/day \\
\hline 2 & Safety Device & Thermostat \\
\hline 3 & FP Collector & 1 Nos \\
\hline 4 & Rated Pressure & $5 \mathrm{bar}$ \\
\hline 5 & No. of Outlet/Inlet & $1 / 1$ \\
\hline
\end{tabular}

Basically the PVT module represented in Fig. 1 tested in the project is made by the combination of these components. 


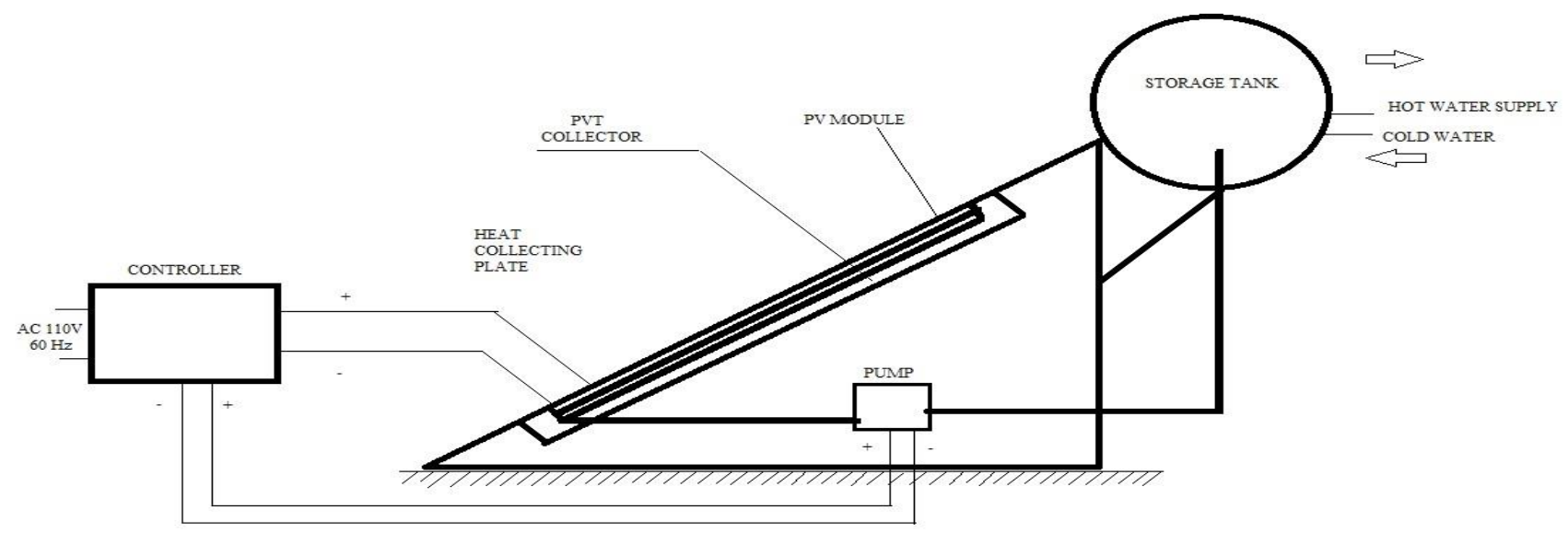

Fig-1: Systematic Diagram of PVT system (Water PVT System)

Various measuring devices are used to detect/evaluate different parameters to collect data presented in the Table 4.

Table-4: Measuring Instruments

\begin{tabular}{|c|c|c|}
\hline S. No. & Instrument & Parameter Measured \\
\hline 1 & Solar Module Analyser & Electrical Characteristics \\
\hline 2 & Solar Power Meter & Global Radiations \\
\hline 3 & $\begin{array}{c}\text { Arduino based Temperature } \\
\text { (Data Logger) }\end{array}$ & $\begin{array}{c}\text { Temperature } \\
\text { (Inlet and Outlet) }\end{array}$ \\
\hline 4 & IR Thermometer & $\begin{array}{c}\text { Front and Back } \\
\text { Temperature of Panel }\end{array}$ \\
\hline
\end{tabular}

\section{METHODOLOGY}

During the period of experimentation, the PVT system is operated to calculate the values/parameters at different stages.

The details are calculated over a period of one month of March 2020 and 6 hours of day divided into period of one hour each (10:00 AM to 4:00 PM).

During the operation the water is circulated through the tank continuously lowering down the temperature of PV panel continuously and parameters like Open Circuit Voltage (Voc), Short Circuit Current (Isc), Atmospheric Temperature C, Panel Temperature $\mathrm{C}$ are collected through different measuring devices $[14,15]$. The same procedure is repeated for the PV system alone simultaneously and the same detailed parameters were recorded.

\section{A. Efficiency of the PV module}

The PV module efficiency found out at instantaneous input solar radiation and instantaneous PV module peak Power is

$$
\begin{aligned}
& \eta=\frac{P_{\max }}{P_{i n}}=\frac{V_{m} I_{m}}{P_{b n}}=\frac{V_{O C} I_{S C} F F}{P_{b n}} \% \\
& \text { Or }
\end{aligned}
$$

$$
\begin{aligned}
& \text { Efficiency } \\
& \qquad \eta=\frac{V_{o c} \times I_{s c} \times F \cdot F}{\text { Rated Power } \times \text { Area }}
\end{aligned}
$$

\section{SYSTEM ANALYSIS}

Global solar radiation is also depicted for an appropriate evaluation of the electrical and thermal systems of solar radiation. For the decided evaluation period, When global solar radiation hits the solar panels and collectors, between 10:00 a.m. and 4:00 p.m. the trend of PV and PVT electrical efficiencies is almost constant or equal to approximately on an average $9.8 \%$ and $12.31 \%$, respectively

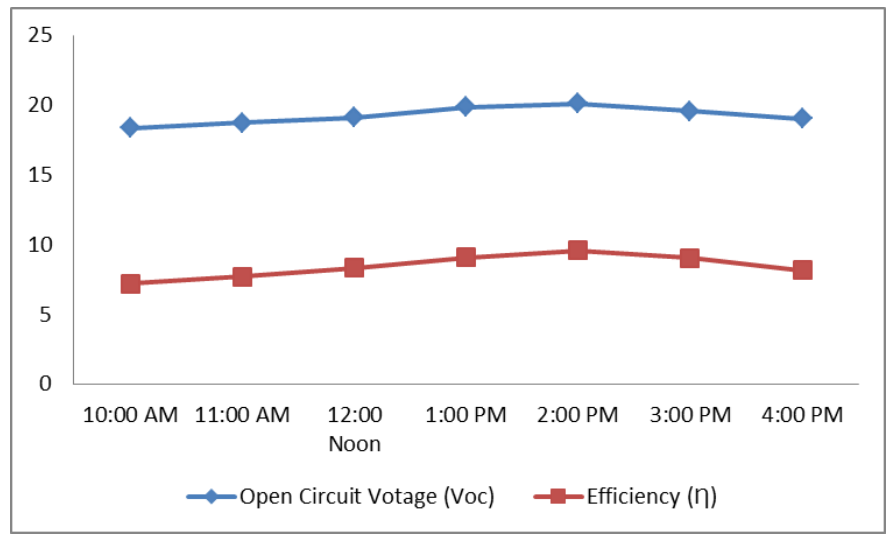

Graph-1: Voltage and Efficiency with time without Water system

The above observation represents the recorded details for the month of March 2020 for PV and PVT system, Power Output, fill factor, and efficiency with respect to the obtained open-circuit voltage, and short circuit current is recorded on an hourly basis from 9:00 AM to 4:00 PM. The PVT system performance is separated into electrical and thermal efficiencies out of which the electrical efficiency is almost stable.

The variation in the temperature of PV panels and PV/T panels as in solar energy temperature plays an important role in performance. As PV/T water system is in operation, it is obvious that the temperature of the PV/T system is lower than that of the PV Panel. The variations in the back panel's temperature also vary in the range of $24^{\circ} \mathrm{C}$ to $40^{\circ} \mathrm{C} \&$ the front temperature varies between $35^{\circ} \mathrm{C}$ to $50^{\circ} \mathrm{C}$. The Dust particle percentage on the panel cell also affects the thermal output as it is clearly visible in the graph-3. 


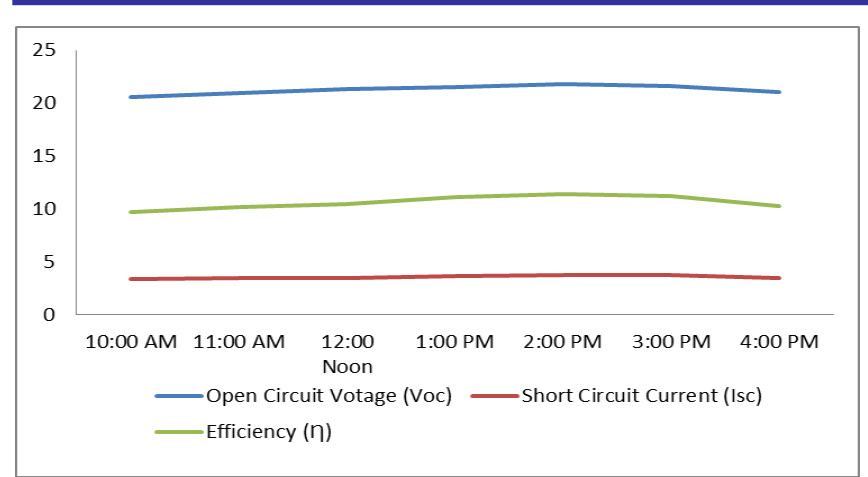

Graph-2: Voltage, Current and Efficiency with time when System is operating as PVT system with water

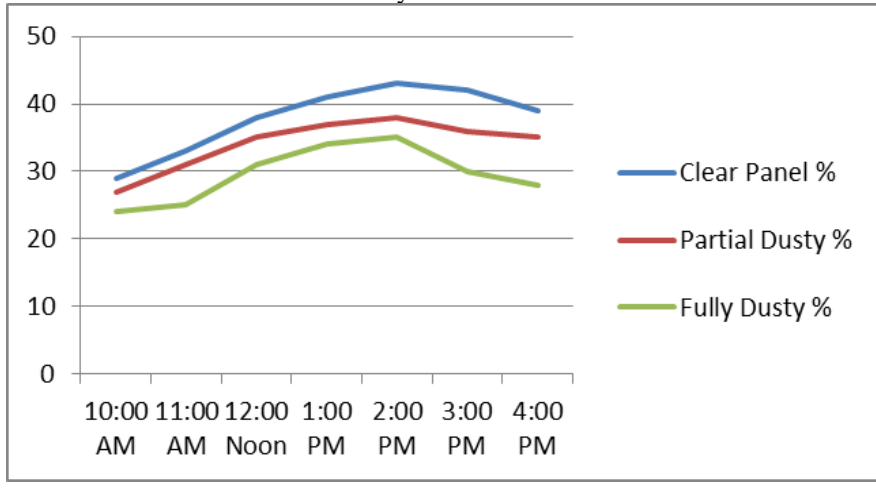

Graph-3: Thermal Efficiencies at different conditions with time

\section{OVERALL EFFICIENCY}

By combining the values of the average thermal and electrical efficiencies, the overall energy performance of the collectors can be analyzed. The selection of an optimal configuration will depend on the overall cost efficiency and energy balance of the system [16]. It is also clear that the electrical efficiency of PVT collectors depends on the cooling effect of the PV module from the PVT inlet fluid temperature and solar radiation along with all aspects of water plays a major role in holding PV cell temperature lower.

Table-4.1: Analysis of Photovoltaic Module with temperature for single day $10 / 03 / 2020$

\begin{tabular}{|l|l|l|l|}
\hline Temperature & $\begin{array}{l}\text { Panel } \\
\text { Temperature } \\
\mathrm{C})\end{array}$ & $\begin{array}{l}\text { Power Output } \\
(\mathrm{W})\end{array}$ & $\begin{array}{l}\text { Electrical } \\
\text { Efficiency }\end{array}$ \\
\hline Average & 40 & 53.84 & 9.7 \\
\hline Minimum & 22 & 39.62 & 8.89 \\
\hline Maximum & 47 & 55.35 & 9.57 \\
\hline
\end{tabular}

Table-4.2: Analysis of Hybrid photovoltaic module with weather condition for a day $10 / 03 / 2020$

\begin{tabular}{|l|l|l|l|}
\hline Temperature & $\begin{array}{l}\text { Panel } \\
\text { Temperature } \\
\text { C) }\end{array}$ & $\begin{array}{l}\text { Power Output } \\
(\mathrm{W})\end{array}$ & $\begin{array}{l}\text { Electrical } \\
\text { Efficiency }\end{array}$ \\
\hline Average & 38.5 & 64.64 & 12.39 \\
\hline Minimum & 24 & 47.65 & 11.76 \\
\hline Maximum & 40 & 69.54 & 12.46 \\
\hline
\end{tabular}

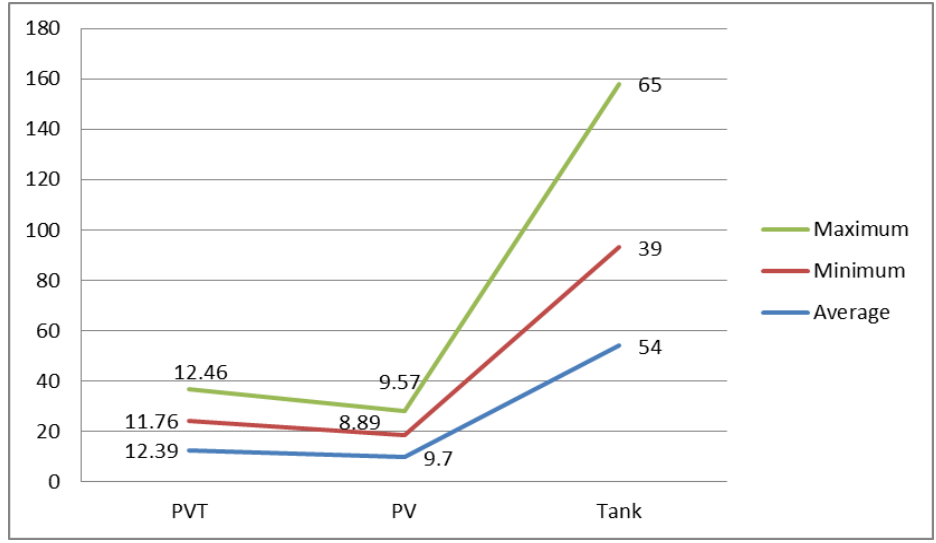

Graph-4: PV and PVT system electrical efficiency for Maximum, minimum and average values.

VIII. CONCLUSION AND RECOMMENDATION

Hybrid PVT solar water system can be applied simultaneously tohouses and other building types for the production of electricity and hot water and is especially suitable for applications with high solar radiation values and normalized temperatures.

The experimental results of the tests clearly concluded that PVT systems can provide hot water for domestic purpose and electricity at sufficient level, which is our main motive before the experimentation. The increase in efficiency is also observed in PVT system as compared to PV cells, The increase is similar to the pattern discussed in the earlier studies depending upon their researches.

The Final Conclusion showed that

1. The performance is affected by the temperature, but as the temperature keeps on increasing, the system will need more time to reach steady state.

2. PVT system is characterized as nearly $40 \%$ more efficient than comparable conventional system

3. PVT/Water system will be the good alternative choice for the generation of electricity and hot water simultaneously at low latitude area.

Future recommendation for this type of model will focus on efficient testing and exploration of its uses during peak summer season, when it is not easy to keep the water cold at the outside temperature of nearly $45 \mathrm{C}$ to $50 \mathrm{C}$. Exploring the options to modify the system as per other regions .

\section{ACKNOWLEDMENT}

I thank Asst. Prof. Neeraj Sharma, Asst. Prof. Simarpreet Singh, Asst. Prof. Simranjeet Singh for their expertise and assistance throughout all aspects to carry out the research.

\section{REFERENCES}

[1] Sahota, L.; Tiwari, G.N. Review on series connected photovoltaic thermal (PVT) systems: Analytical and Experimental Studies. Sol/Energy 2017, 150,96-127.

[2] A.Hegazy,"A Comparative study of the performances of four photovoltaic/thermal solar air collectors"; Energy Convers. Manage. Pp.861-881.

[3] Performance Review of Photovoltaic Thermal System; Amandeep Singh, Neeraj Sharma, Harnik Singh, IJRASET, Vol 8 Issue IV Apr 2020, pp 210-215.

[4] Fraisee G., Souyri B.: 2003, Rapport Programme Energie CNRS: “ Compte rendu scientifique: conception d'un capteur PV/T- eau. Rapport premie`re anne`e. PRI 6.2, Inte`gration de capteurs hybrides photovoltai ques thermiques au ba ti, pp.56. 
[5] Loferski J. J., Ahmad J. M., Pandey A.: 1988.Performance of photovoltaic cells incorporated into unique hybrid photovoltaic/thermal panels of a $2.8 \mathrm{~kW}$ residential solar energy conversion system/In Proceedings of 1988 annual meeting. American Solar Energy Society. Cambridge, USA, pp. 427-32.

[6] Garg H. P., Adhikari R. S.: 1997. Conventional hybrid photovoltaic/thermal (PV/T) air heating collectors. steady-state simulation. Renewable Energy, Vol. 11, No. 3, pp. 363-85. http://dx.doi.org/10.1016/S0960-1481(97)00007-4

[7] Vries D. W.: 1998. Design of a Photovoltaic/ Thermal Combi-panel. $\mathrm{PhD}$ thesis. Eindhoven University of Technology. Netherlands.

[8] Coverntry J.S., Lovegrove K. Developmen of an approach to compare the value of electric and thermal output from a domestic PV/Thermal system Solar Energy, 2003; 75:63-72.

[9] Leenders F.Shaap A.B, van der Halden B.G.C. Technolgy review on PV/Thermal concepts. In proc. $16^{\text {th }}$ European PV Solar Energy Conferennce, 1-5 May, Glasgow, U.K. 2000; pp 1976-1980

[10] Tripanagnostopoulos Y., Nousia Th., Souliotis M. and Yianoulis P. hybrid Photovoltaic/ Thermal solar systems. Solar Energy, 2002, $72,3: 217-234$
[11] Lasnier F. amd Ang T.G Photvoltaic Engineering handbook Adam Higler 1990; 258.

[12] Chow TT. A review on photovoltaic/thermal hybrid solar technology. Appl Energy 2010; 87: 365-379.

[13] B.J. Huang, T.H. Lin, W.C. Hung and F.S. Sun; Performance Evaluation of Solar Photovoltaic/Thermal Systems; Solar Energy Vol 70, No.5 pp 443-448

[14] Kern EC Jr. and Russel MC; "Combined photovoltaic and thermal hybridcollector systems". In: Proceedings of the 13 th IEEE photovoltaic specialists, Washington DC, USA, Pp. 1153-57, 1978.

[15] Shan, F., Tang, F., Cao, L. and Fang, G.; "Performance evaluations and applications of photovoltaic-thermalcollectors and systems". Renew. Sustain. Energy Rev. 33, Pp. 467-483, 2013.

[16] Pooja Shukla, Nilesh Diwakar and Namish Mehta, Design and installation of a combine PV-Thermal system with increased effciency using composite PCM, IJLTET Vol8, Issue IV, pp 15-24

[17] P.G. Charalambous et.al. PhotovoltIC Thermal(PV/T) collectors A review"; Applied Thermal Engineering 27 920070 275-286. 